\title{
FAIR AND EQUITABLE TREATMENT STANDARD IN NTERNATIONAL INVESTMENT AGREEMENTS
}

\author{
Sefriani \\ The Faculty of Law, Indonesian Islamic University \\ E-mail: sefriani@uii.ac.id
}

\begin{abstract}
In the last five years, the number of investors who suit against host state in the international arbitration forum increased significantly. Almost all lawsuits used fair and equitable treatment (FET) standard which has been violated by the host state. Most of international investment agreements including those that were made by Indonesia contain FET standard clauses. However, there are no definitions related to this standard. This condition potentially raises a very wide interpretation of the standard. The problem formulations in this article are how the history of FET is, where its position in international investment law is and what elements of FET standard are. The results show that the FET standard has existed since Havana Charter followed by various FCN, BIT and other international investment agreements. FET standard can be categorized as customary international, legally binding on all countries regardless their national law. Although there is no universal approval regarding the scope of FET standard, the writings which have been published and the arbitral tribunal decision mentions that those elements are legitimate expectation; due process; denial of justice; rule of law; nondiscrimination; transparency; consistency, good faith, and reasonableness.
\end{abstract}

Keywords: Fair and equitable treatment standard; international law; international investment law

\section{A. INTRODUCTION}

In recent years, the number of lawsuits facing Indonesia in the international arbitration forum has increased significantly (Indonesia for Global Justice:2017: $\quad$ http://igj.or.id/wp-content/uploads/2017/01/Akhir-dari-sengketaPerjanjian-Internasional.pdf). In eleven year period of 1999-2010, the number of foreign investors who suit against the Indonesian government was 5. However, from 2011 to 2016, which only lasted 5 years, there were 5 cases, namely cases of Ravat Ali Rizvi (CenturyBank case) - 2011, Churcill Mining and Planet Mining (2012), Newmont Nusantara BV (2014), Indian Metals and Ferro Alloys Ltd (IMFA) September 2015, and Oleovest Pte.Ltd (2016) (Indonesia for Global Justice:2017:http://igj.or.id/wp-content/uploads/2017/01/Akhir-dari-sengketaPerjanjian-Internasional.pdf). 
For example, in the case of Heslam Talaat, the plaintiff claimed that Indonesia violated the FET standard under the OIC agreement. This is because after the Century Bank was taken over, the plaintiff was investigated for alleged violations of bank regulations, buying over, and criminal prosecution in Jakarta central court. This, according to the plaintiff, was very unfair, a denial of justice, and a violation of FET obligations. Criminalization of it has caused mental, financial, and personal image and ongoing business affairs. The Plaintiff stated his loss due to criminalization is more than USD 20 million(Award on Respondent's Preliminary Objections to Jurisdiction and Admissibility of the Claims, He Sham Talaat M.Al Al Warraq vs Republic of Indonesia, 21106/2012:par. 46-47).

Furthermore, in the case of Rafat Ali, Indonesia has also been sued for violating Articles 4 and 2 (1) Bilateral Investment Treaty (BIT) of Indonesia-UK on FET (ICSID Case No. ARB/11/13):par. 206). Churchill mining also used FET violations in its lawsuit addressed to Indonesia in 2015.

The large number of lawsuits using FET standard has led countries to seriously pay attention to this standard. There are at least two issues that are recorded and become a serious talk of the international community today. First is the debate on the position of FET standard in international investment law. Up to now the FET standard has often been regarded as an absolute requirement for the host state that wants investment to come into its territory. Host states seem to have no choice but to include FET standard in their signed investment agreements and even adopt them in their national law. This standard is often considered to be too favorable to the interests of investors and to harm the host state.

The second problem is on the scope of the FET standard. In general, many international investment agreements including BIT do not in any way define what is meant by the FET Standard. Even if so, the definition is a very broad (openended language) so as to open the opportunity to be defined very broadly by each party or by the arbitrator in the Investor-State Investment Dispute (ISDS) forum, so that almost all state actions that harm investors can be claimed to violate this standard. BIT of Indonesia itself does not provide a definition of FET standard. For example, Article 3 (2) BIT of Indonesian-Indian stipulates the following: (Agreement between the Government of the Republic of Indonesia and the Government of the Republic of India regarding the Increase and Protection of Investment: 1999: 3)

"Investments and revenues by investors of either contracting party shall at all times be reasonably and equitably treated in the territory of the other Contracting Party."

Article 4 of BIT of Indonesia-India stipulates as follows: 
"Investments made by an investor of either contracting party in the territory of the other contracting party shall receive a fair and equitable treatment and no less favorable than that granted to investments by Third country investors."

Another example is Article 2 (2) of the BIT of Indonesia-Australia which stipulates: A party shall ensure fair and equitable treatment in its own territory to investment (Agreement between the Government of the Republic of Indonesia and The Government of Australia concerning the promotion and protection of Investment:1992:4).

Similarly Article 3 (2) of BIT of Indonesia-United Kingdom stipulates as follows: (Agreement between the government of republic of Indonesia and the government of The United Kingdom of great Britain and northern Ireland for the promotion and protection of investment: 1976:4).

" Investment of nationals or companies of either contracting party shall at all times be accorded fair and equitable treatment and shall enjoy full protection and securities in the territory of the other contracting party. Each contracting party shall ensure that the management and maintenance using enjoyment or disposal of investment in its territory of nationals or companies of the other contracting party are not in any way impaired by unreasonable or discriminatory measures. Each contracting party shall observe any obligation it may have entered into with regard to investment of nationals or companies of the other contracting party."

There is no explanation on what is meant by FET standard which must be given by each party in several BITs above. Several BITs made by Indonesia generally only contain definitions of investment; investors; revenues (returns); and territory but there is no definition of FET. It is, surely, very risky, when there is a condition in which an Indonesian policy is considered detrimental to investors; generally they will use the article about the FET guarantee and even the guarantee of enjoy full protection and securities as stated in BIT of Indonesia-UK. The lack of clarity on standard FET parameters often raises the question whether it must be an arbitrary conduct or merely an act of evenhandedness to be called violating the FET (Robert Wisner: 2007: 129).

Based on the above explanation it is important to see how the history of FET is, where its position in international investment law is and what elements of FET standards is used to see when the country is claimed to have violated the FET standard. With a good understanding of FET standard it is expected that Indonesia can provide a clear limit in international investment agreements it creates and can 
defend itself well if there is a lawsuit on the basis of a violation of the FET standard.

\section{B. PROBLEM STATEMENTS}

1. How is the history of FET standard and where is its position in international investment law?

2. What are the elements of FET standard used to see when the country is claimed to have violated the FET standard?

\section{DISCUSSION AND RESEARCH RESULT}

\section{The History of FET Standard and Its Position in International Investment Law}

FET standard is a very fundamental standard in international investment agreements. This standard has already been written in various international investment agreements, but there is very little academic attention, and there are few writings analyzing the implementation and measurement of this standard, whereas in the past decade there was an increase in lawsuits against host states in ICSID forum using FET violation standard. (Stephan W Schill: 2006: 1)

The FET standard becomes a fundamental standard in the practice of international investment agreements especially after the launch of Havana Charter for an International Trade Organization, Mar. 24, 1948. (Kenneth J. Vandevelde: 2010: 44) (Stephen Vasciannie: 2009: 99) Article 11 (2) (a) (i) The Havana Charter calls every country:"to assure just and equitable treatment for the enterprise, skills, capital, arts and technology brought from one member country to another."

Although the Charter never applies, the call affects the practice of Friendship, Commerce and Navigation (FCN) agreement made by the U.S. with its partner countries after World War II, which requires a fair and equitable treatment of foreign-owned property in it. (Kenneth J. Vandevelde: 2010: 44) For example article I sec. 1 of the 1954 Treaty between Germany and the United States establishes: "Each Party shall at all times accord fair and equitable treatment to the nationals and companies of the other Party and to their property, enterprises and other interests (Treaty of Friendship, Commerce and Navigation: 1954: 4).

Further clauses containing FET standard are also found in codifications of investor rights. The 1959 Draft Convention on Investments Abroad, so called Abs-Shawcross Convention. Article 1 of this instrument requires "each party shall 
at all times ensure fair and equitable treatment to the property of the nationals of other parties. "In addition, Article 1 (1) of the 1967 OECD Draft Convention on the Protection of Foreign Property sets a similar thing. Hereinafter this clause is like becoming standard clause in various modern BITs (Robert Wisner: 2007:89).

Treaty for the Promotion and Protection of Investments of Germany and Pakistan 1959 is the first BIT to contain a FET standard clause (Kenneth J. Vandevelde: 2010: 45). In 1960s other countries began to incorporate FET standard clauses in their BIT. In this way the FET standard clause is considered to be a standard clause.

BIT format of various countries is generally the same. It consists of preamble which aims to increase the economic cooperation between home state and host state, providing protection of foreign investors in the host state region that provides benefits to both parties. FET becomes the minimum standard in BIT. The formulation of FET in various BIT is highly variable, sometimes associated with international law; minimum standards of customary international law, not infrequently also not associated with anything, and just to be FET standard with additional unreasonable and discriminatory measures as exemplified by BIT of Dutch and the United Arab Emirates (Dagbjort Hauksdottir: 2014: 5).

Not only bilateral agreements but also regional agreements such as NAFTA include FET as one of the standards that must be met. NAFTA created by Mexico, Canada and the United States in 1992 includes trade in goods, services, government procurement and other vital investments. (Dagbjort Hauksdottir: 2014: 6)

For example Chapter 11 Section A of NAFTA requires at least 7 major guarantees that a host state must provide for foreign investors:

(1) national treatment,

(2) most-favored-nation treatment,

(3) fair and equitable treatment in accordance with international law,

(4) full protection and security in accordance with international law,

(5) non-discriminatory treatment in case of armed conflict or civil strife,

(6) free transfer of capital related to foreign investment or foreign investors, and

(7) non-discriminatory expropriation followed by fair compensation

All three NAFTA's requirements include FET standard in accordance with international law, but the interpretation of which is not specifically explained in the document. In addition to NAFTA, the FET standard is also found in Article 10 of the 1994 Energy Charter Treaty stipulating that treaty provides protection that is not less favorable than what international law required, gives constant 
protection and security, and finally prevents unreasonable and discriminatory measures (Dagbjort Hauksdottir:2014:5).

Like the BIT, regional and global agreements do not provide definitions and parameters of FET standard. Today the FET standard is to be an absolute requirement which must be given to foreign investors by the host state. Although its position and scope in investment law are unclear, the FET standard is present in the majority of regional and global bilateral investment agreements.

Up to now the debate on FET standard position with a variety of opinions is still ongoing. According to Dumberry, some international jurists in their publications wrote that FET standard in international customary law is given that so many BIT contain FET standard in their clauses (Patrick Dumberry:20152016:68).

However Dumbery does not agree with these writings because according to him the requirement to be regarded as an international custom law has not been met by FET standard. In his research, only two decisions were found, namely the UNCITRAL decision of 2002 in the case of Pope and Talbot Inc. vs Canada and Merril and Ring Forestra interpreting FET status. In the case of the pope and Talbot tribunal the FET is an additional standard outside the customary international law (Patrick Dumberry: 2015-2016: 69).

In addition, according to Dumberry, although many domestic foreign investment laws in developed and developing countries protect foreign investors with FET standard (Alexandra Diehl: 2012: 174), most of domestic laws do not mention the direct FET but only protection of investment under international law. Of the 165 statutory regulations tested only about ten are explicitly mentioned the FET standard (Patrick Dumberry: 2015-2016: 73).

Therefore, according to Dumberry, FET standard is obligations born under international agreements such as BIT, but not international customary law (Patrick Dumberry: 2016: 47). This opinion still invites much debate such as whether international customary law can be born out of international treaties. The large number of international investment agreements such as BIT which always contain FET standard clauses can make this standard an international custom law if it supported by a jurist opinion.

Although there is currently no universal agreement on FET standard position, according to Ignacio Pinto-León there are at least 3 approaches which are often used to interpret the FET principle, ie: (Ignacio Pinto-León:2006:6)
a. as part of the minimum standard required by customary international law (C.I.L.),
b. as part of international law in general - customary and treaty based,


c. as an independent self-contained standard.

FET as part of the minimum standard of customary international law is included in the decision of L.F.H. Neer and Pauline Neer (U.S.A.) vs United Mexican States U.S.-Mexico Gen'l Claims Comm'n 4 R.I.A.A. 60 (Oct. 15, 1926). This case is a claim against Mexico due to the death of miners, US Navy, in Mexico. The American commission accuses Mexico of failing to investigate the case, as well as punishing the perpetrators. The court concluded that government action would violate the minimum standard of treatment only when it was "amount to an outrage, to bad faith, to willful neglect of duty, or to an insufficiency of government action so far short of international standards that every reasonable and impartial man would readily recognize its insufficiency." ( Ignacio Pinto-León:2006:6)

Some BIT that link fair and equitable treatment with customary international law include Agreement on the Reciprocal Promotion and Protection of Investment, between France and Mexico Nov. 12, 1994. Article 4 (1) of this BIT presupposes that:

Each contracting party shall undertake to accord in its territory and maritime zone just and equitable treatment, in accordance with the principles of international law, to the investments made by investors of the other Party and to ensure that the exercise of the right so granted is not impeded either de jure or de facto."

Unfortunately, the article above does not provide a clear definition of the standard in question (Kenneth J. Vandevelde: 2010:46). Treaty on the Encouragement and Reciprocal Protection of Investment, between U.S.-Uruguay Nov. 4, 2005 also links the FET standard with customary international law by giving a little explanation in Article 5 in which international customary law definesthe minimum standard of treatment of aliens. The BIT also explains that the concepts of 'fair and equitable treatment' and 'full protection and security' do not require treatment in addition to or beyond that which is required by that standard, and do not create additional substantive rights (Kenneth J. Vandevelde:2010:47).

In contrast the BIT of the US and Grenada allows the FET standard to exceed what is stipulated in international customary law.

Article 1,105 of the NAFTA entitled Minimum Standard of Treatment sets out: "fair and equitable treatment" is included along with "full protection and security" as one of two examples of "treatment in accordance with international law.Interpretation of Article 1,105 given by NAFTA is that it reflects minimum 
standard of treatment in international customary law and does not require any treatment beyond that. Article 1,105 of NAFTA, establishes as follows:

1. Each party shall accord to covered investments treatment in accordance with customary international law, including fair and equitable treatment and full protection and security.

2. For greater certainty, Paragraph 1 prescribes the customary international law minimum standard of treatment of aliens as the minimum standard of treatment to be afforded to covered investments. The concepts of "fair and equitable treatment" and "full protection and security" do not require treatment in addition to or beyond that which is required by that standard, and do not create additional substantive rights. The obligation in Paragraph 1 is to provide that

a. fair and equitable treatment" includes the obligation not to deny justice in criminal, civil, or administrative adjudicatory proceedings in accordance with the principle of due process embodied in the principal legal systems of the world; and

b. full protection and security" requires each party to provide the level of police protection required under customary international law. (Robert Wisner:2007:131-132)

The Neer case is an old case that is always referred to in the ICSID arbitration forum. Nevertheless the FET standard has evolved so far more than what the judge put forward in Neer's case (Dagbjort Hauksdottir: 2014:13).

Unclear standards in customary international law make international organizations such as the OECD try to interpret them. Article 1 of draft convention on the protection and foreign property states that the host states' main obligation is to respect and protect the property of foreigners in their area. This has become a common practice of international law. The fair and equitable treatment phrases found in BIT constitutes international customary law including each party honoring the foreign property. States are expected to adopt in their national law the provisions of this international law standard. What the OECD does is an early attempt to interpret FET scope. Other efforts are also made by NAFTA Free Trade commission (Dagbjort Hauksdottir: 2014:14).

Being independent, FET standard set by international law rejects the idea of linking FET with minimum treatment standards. The FET is considered a selfcontained standard that is very casuistic depending on the interpretation of the arbitrator. Support for this opinion is based on the belief that there are different standards between what developed and developing countries have so that it is difficult to find fair standards for those two different camps of interest. Besides, 
fair and equitable are two different things. It could be treated fair and equitable, unfair but equitable, or vice versa (Dagbjort Hauksdottir: 2014:19).

In the case of Saluki vs. Chech Republic, the court ruled that being independent FET standard must be interpreted according to the object and purpose of its international agreement.

Another opinion says that the FET standard differs from the international minimum standard (IMS) treatment of foreigners. IMS is described as an obligation on states to ensure that 'aliens are treated in accordance with the ordinary standards of civilisation' 9 irrespective of the standards they accord to their nationals (Hussein Haeri, 2011:28).It is clearly an international customary law governing the relationship between host state and foreign investors, binding on countries, regardless of what is set in its national law. IMS is the minimum standard that arises from investor dissatisfaction with the host state treatment uncivilized, arbitrary, and unable to ensure the rule of law (Olatokunbo LadOjomo:http://citeseerx.ist.psu.edu/viewdoc/download?doi=10.1.1.473.6169\&rep= rep1\&type=pdf:13-14) Although it has not yet reached a universal agreement, the IMS generally covers:

a. The administration of justice to aliens (particularly denial of justice cases)

b. Treatment of foreigners under detention

c. Full Protection and Security

d. The manner of expulsion of foreigners from host states (Olatokunbo LadOjomo:http://citeseerx.ist.psu.edu/viewdoc/download?doi=10.1.1.473.6169\&re $\mathrm{p}=$ rep1\&type=pdf:15).

The FET standard is broader in scope than the IMS that it cannot be said that FET is an international customary law such as IMS. On the other hand, the NAFTA general view of the tribunal and the OECD countries state that the FET standard is an element of the current customary international law minimum standard of treatment, and no additional treatment above the minimum standard is required to satisfy the FET standard (Olatokunbo Lad-Ojomo: http://citeseerx.ist.psu.edu/viewdoc/download?doi=10.1.1.473.6169\&rep=rep1\&t ype=pdf:15) Meanwhile in Saluka case, the tribunal interpreted the FET provision in the BIT as an autonomous treaty standard in accordance with the rules of interpretation (Olatokunbo Lad-Ojomo: http: // citeseerx. ist. psu. edu / viewdoc / download?doi=10.1.1.473.6169\&rep=rep1\&type=pdf:18)

From the above explanation, it appears that the position of the FET standard is not yet clear. There are at least 2 opinions about this position. The first is that the FET standard is not an international custom but is an obligation arising from an international investment lease. This means that the FET standard is 
independent, not tied to the IMS, and depends on what is set in its international agreement. Consequently, the FET standard is binding only to the parties in the agreement itself. The second is that the FET standard is part of the IMS which is an international customary law. As a consequence, this standard is a binding obligation for all countries. Against this second opinion there is an opinion that the FET standard is customary international law, not beyond what is required by IMS treatment of foreigners. On the other hand there is other opinion that FET standard is possible beyond the IMS.

\section{Elements in the Clauses of FET standard}

Before the 20th century protection for investors was only provided through diplomatic channels. This is an indirect form of protection because the fate of the investor depends on the origin country. At the end of the second world war, many countries realized the importance of investment for economic development. To attract foreign investors, host countries provide protection for foreign investors through BIT, which is sometimes even greater than that provided for domestic investors (Dagbjort Hauksdottir: 2014:4).

In the late 1980s, the number of BIT increased dramatically to 2000s in which the majority of it contained FET standard clauses (Kenneth J. Vandevelde: 2007: 46) which are highly variable and generally do not provide definition. Generally the FET standard clause attributes this standard to a non-discriminatory principle such as MFN. For example, BIT of Iran and Bangladesh states that each party is obliged to give" fair treatment not less favorable than that accorded to its own investors or investors of any third state, whichever is more favorable"(Kenneth J. Vandevelde:2007:46). Of course, such formulations do not clarify what is meant by FET standard. The absence of parameters in various BIT or other international investment agreement forms makes the term "fair and equitable" freely interpreted by international legal authors as well as judges through their verdict in court forums or arbitral tribunals. Eventually FET interpretation develops through the opinions of experts and court or arbitration decisions.

FET legal sources that are often used by international legal writers and judges in their decisions include: the statute of the international court, especially article 38 on the sources of HI; the ICSID convention whose article 42 mentions that when no applicable law is selected, the judge may use HI which may become an applicable law; Article 31 VCLT which is the article on the general rule of interpretation of the treaty base on customary international law. In the case of Azuric vs Argentina, the tribunal states that the FET interpretation must be based 
on Article 31 VCLT which stipulates that a treaty treatment should be conducted with good faith in ordinary meaning.

From the various cases it appears that the tribunal no longer associates the FET standard with the minimum standard of treatment of foreigners due to the lack of clarity of its elements. Tribunal already identifies the 5 elements of different situations found in different cases. The five elements are: investor's legitimate expectation, transparency, due process; acting in good faith; and freedom from coercion and harassment (Rudolf dolzer and Christoph schreuer: 2012:145).

Sornarajah who quoted NAFTA tribunal awards, in the case of Metalclad said that the lack of transparency also resulted in FET violations. Sornarajah notes the existence of two types of state actions violating the FET: denial of justice and lack of due process or administrative irregularity.

Court practice, as well as FET standard, generally avoids providing grand theory. It only provides examples of types of behavior that violates the FET standard. The first FET-related verdict in a modern investment agreement can be found in the case of Azinian vs Mexico (Azinian vs United Mexican States, ICSID Case No. ARB (AF)/97/2, Award dated 1 Nov. 1999, 39 I.L.M. 537 (2000) in front of the ICSID forum in 2000. In this case the investor suspended the termination of the concession contract in front of the ICSID after losing before the Mexco court. ICSID in its verdict stated that the decision of cancellation of the contract by the court can only be opposed directly or indirectly if there is a denial of justice, and Mexico does not do that. This case shows the importance of what interpretations lead to FET violations. This verdict does not review the regulatory conduct of Mexico but rather focuses on the treatment of contractual rights of foreign investors by local courts (Robert Wisner:2007:130).

In the case of Waste Management vs Mexico, ICSID provides illustrations of host state behavior, which is arbitrary, grossly unfair, unjust or idiosyncratic, as discriminatory and exposes the claimant to sectional or racial prejudice or involves a lack of due process leading to an outcome which offends judicial propriety--as probably the case with a manifest failure of natural justice in judicial proceedings or a complete lack of transparency and candor in an administrative process is a behavior that violates the FET standard (ICSID Case No. ARB (AF)/00/3, Award, P 98 (Apr. 30, 2004), 43 I.L.M. 967).

The existence of the FET Standard Clause is intended for the stability of the implementation of the investment. For example, Preamble of BIT of The USArgentina of 1991 states that: "fair and equitable treatment of investment is desirable in order to maintain a stable framework (Rudolf Dolzer: 2005:90).In fact, it is not easy to set a standard for this clause. Rudolf Dolzer writes the FET 
standard developed from consistency of governmental action and stability of longterm arrangements and commitments. He also added good faith, transparency and due process fulfillment, are often referred to as a requirement to meet FET standard (Rudolf Dolzer: 2005:100,106). Meanwhile Christoph Schreuer added terms of principles of transparency, the protection of the investor's legitimate expectations, freedom from coercion and harassment, procedural propriety and due process, and good faithas the content of the FET standard (Christoph Schreuer: 2005:359).

Rubens and Kinsella identify a violation that includes a FET violation is when the host state fails to: provide a stable and predictable investment environment, keep the arrangements "in reliance upon [which] the foreign investor was induced to invest," and keep the stability of the legal and business framework (Noah D. Rubins \&\& N. Stephan Kinsella: 2005: 214-216).

Furthermore, Barnali Choudhury adds transparency, due process, and good faith and prohibited breach of legitimate expectations, arbitrary or discriminatory conduct, and acts beyond the scope of legal authority as requirements of FET standard (Barnali Choudhury: 2005: 297). Jean Kalicki and Suzanne Medeiros state the two important requirements that are usually used by the court, namely: the standard protects investors' legitimate expectations and the other in which it prohibits manifestly arbitrary conduct (Jean Kalicki \& Suzanne Medeiros: 20017:26).

The highly varied elements of the FET standard make some authors express their concern that the addition of principles without the coherent theory of fair and equitable treatment guidance encourages the courts to give too much discretion to the interpretation of this standard(J. Roman Picherack:2008:261).

Several other decisions state the standard elements of FET, among others, are transparent, non-arbitrary, non-discriminatory, fulfill the investor's legitimate expectations, follow due process, not be abusive (i.e. be free from coercion, duress and harassment) (Matthew Coleman, Helen Aldridge, Thomas Innes: 2015: 1). Based on the opinion of legal experts and court decisions or arbitral tribunal as described above it appears that there is no universal agreement of FET standard parameters. Nevertheless it can be concluded that there are standard elements always mentioned by almost all authors as well as some tribunal arbitral decisions for the fulfillment of FET standard. In other words, the violation of these elements is a violation of the FET standard. The standard elements are as follows: 


\section{i. Element of Legitimate Expectation}

Legitimate expectation is a new standard in international investment law. However, it does not mean that this standard can be interpreted as freely as possible by the courts. According to Wisner, legitimate expectations should be established with an objective test, although the available evidence is the subjective intention of the state, as well as that of relevant investors. Legitimate expectation comes from: the host state's regulatory framework, the representations of its government officials and the reasonableness of the investor's reliance on the stability of the regulatory framework (Robert Wisner:2007:129).

Although it is a new standard, legitimate expectation is accepted by many legal systems in the world as a key element of the FET standard. Based on its jurisprudence, legitimate expectation is classified into 3 categories: stability in the legal framework as a whole, stability in the administrative conduct and stability in the contractual relationship with the host state (Roland Klager, 2011: 169, 175 and 180).

Any legal frame work changes potentially violate the FET principle, but it does not mean that the state should freeze its legal system for the benefit of investors. For example, if the state adjusts its environmental legal standard to international standard, it does not make it a violation of the original FET standard to be non-discriminatory and good faith (Christopher Schreuer:2005: 374-375).

Examples of FET violations related to legal framework changes can be found in the case of CMS vs. Argentina. In this CMS case, the American company has a $30 \%$ stake in TGN, the state-owned oil company of Argentina. Initially TGN that had the right to calculate tariffs in dollars then converted to pesos, can determine tariff every 6 months. Permission for TGN is granted for 35 years. In 1990, Argentina experienced a monetary crisis and permanently revoked TGN's right to calculate tariffs and to commission into the peso. CMS feels aggrieved over this policy change and takes its case to arbitration. The CMS accused Argentina of violating the FET standard by altering the stability and predictability of the investment environment. Indeed, the security environment is the first key for investors to invest. Tribunal states that although there is no FET definition in an Argentine-American agreement from a preamble that guarantees FET to maintain stable framework for investment and maximum use of economic resources, the tribunal concludes Argentina has violated the FET standard (Dagbjort Hauksdottir:2014:26).

Stability of the administrative conduct relates to the termination or revocation of administrative decisions such as an investor's operating license. This situation often raises the question which should be of public interest or investor 
expectation. In the case of Metal Clad vs Mexico, the governor issues ecological decree to protect rare cactus plant acreage. The Tribunal declared that Mexico actions that do not provide construction permit are inappropriate. Even if Mexico has the right to require a domestic construct license, the evidence indicates that the evaluation and testing of hazardous wastes are only necessary for a construction permit. Thus the refusal to grant a construction permit on the grounds of environmental effects is inappropriate. In the case of Tecmed vs Mexico tribunal states that the FET standard must give a treatment to investors who do not change their basic expectation (Dagbjort Hauksdottir: 2014: 28).

Related to the stability of the contractual relationship between investor and host, jurisprudences that can be seen, among others, are those in the case of lauder vs Czech Republic and CME vs Czech republic. Based on these two findings, the FET standard protects the host state contractual relationship with foreign investors. How far the contractual protection protected by the FET standard is still vague. Some cases are interpreted broadly and generally by tribunals, while others use different approaches. Some court decisions even interpret that FET standard violations are merely a violation of legitimate expectation of the investors only.

\section{ii. Element of Denial of Justice}

Denial of justice is identified as the absence of due process, lack of transparency, absence of good faith and violation of legitimate expectation in exercising administrative functions associated particularly with licensing. Denial of justice requires a non-compliance with the judicial process by host state using international standard and aligns the host state judicial system with home state. Denial of justice is recognized as FET violation only if the host state legal system fails to provide the most basic remedy to legal injury; or in certain cases all the judicial authorities involved in the adjudication of the legal framework in place. Otherwise, every losing party in a legal proceeding, each believing justice to be in their side, would argue to have suffered a denial of justice (Dagbjort Hauksdottir: 2014:6-7).

Adede adds that denial of justice requires improper administration of civil and criminal justice as regards an alien, including denial of access to courts, inadequate procedures, and unjust decisions. However, the existence of denial of justice does not make the arbitral tribunal an appeal court for domestic host state courts (A.O. Adede:1976:91). 


\section{iii. Element of Rule of Law}

International customary law requires due process before local courts or administrative agencies. Host failure to give this causes a denial of justice that leads to a violation of the FET standard. Thus, FET standard requires consistent behavior related to procedural rule of law. The substantive dimensions of the rule of law are rooted in the nature of the concept. The concept of the rule of law is often contrasted with that of man. It refers to the desire to create a government of laws and "not a government of man" to avoid arbitrariness. In the government of man, the individual is at the mercy of the ruler. In the government of rule, the rulers who are bound by law shall not exercise its authority arbitrarily. The rule of law demands rationality which is the opposite of an arbitrary government.

Law is defined as generalization, requiring that under the same conditions everyone has the same legal consequences. This is called the principle of consistency. Higher levels of law are defined as security, non-discrimination and transparency. In the practice of arbitration rulings there is no consistent relationship between the standards of fair and equitable treatment of procedural and substantive dimensions as described above.

Current modern BIT, according to Kenneth J. Vandeveld, already reflects the concept of rule of law. The National treatment clause and MFN principles reflect the principle of non-discrimination; the prohibition on unreasonable and discriminatory measure clause reflects the reasonableness principle; the requirement of full protection and security reflects the security principle; and the investor-state dispute settlement clause reflects the due process principle (Kenneth J. Vandeveld: 2010:53).

The principles of rule of law are characterized in previous discussions at a high level of generality in which the scope is highly indefinite. For example, the consistency principle seems to prevent the host state from changing its policy. In fact, forbidding the state to never change its policy is absurd and will contradict the principle of reasonableness

\section{iv. Element of Reasonableness}

This element requires reasonable host state action in relation to a legitimate public policy objective. This standard is met even when host state actions are executed poorly or host state fails to advance the policy. The violation of the principle of reasonableness occurs when the measure is not adopted in the pursuit of legitimate host state public policies. Violations occur when the motivation of state action is to retaliate against the actions of foreign investors who are legal but bear unpopular behavior (Kenneth J. Vandeveld:2010:54). 
In the case of Waste Mgmt., Inc. vs United Mexican States, 2004, ICSID, (Waste Mgmt., Inc. vs United Mexican States, ICSID Case No. ARB (AF) / 00/3, Award (Apr. 30, 2004), 43 ILM 967) NAFTA stated that the courts do not judge the wrongness of state policy but judge whether there is an irrational or arbitrary state action. In some cases, the court found that state action was legitimate because it was conducted for legitimate regulatory reasons. For example, in Genin case vs Estonia ICSID Case No. ARB / 99/2, Award (June 25, 2001), ICSID Rev.Foreign Inv. LJ 395 (200)), ICSID states that the action of the Estonian to revoke the bank's permit is reasonable and legitimate given the concerns of the state regarding the management and financial condition of the bank (Kenneth $\mathrm{J}$. Vandeveld: 2010: 55). Violations against the FET standard will occur if the state act indicates the existence of "a willful neglect of duty, an insufficiency of action falling far below international standards, or even subjective bad faith".

In the case of Noble Ventures, Inc. vs Romania (Noble Ventures, Inc. vs Romania, ICSID Case No. ARB / 01/11, Award (Oct 12, 2005), available at http://ita.law.uvic.ca/documents/Noble.pdf) ICSID decides that there is no violation committed by Romanians. The Romanian act of reorganizing the company suspected of its intention to enforce the cancellation of the Romanian privatization agreement with the plaintiff and to regain control of the company, according to the court, is not arbitrary but is the only solution to resolve corporate bankruptcy and his inability to pay four thousand employees. In this case the court seeks a balance of host obligations to provide full protection and security, the prohibition of arbitrary and discriminatory measures, and the obligations to observe contractual obligations towards the investor (Kenneth J. Vandeveld:2010:56).

In the case of Parkerings-Compagniet AS vs Republic of Lith 2007(Parkerings-Compagniet AS vs Republic of Lith., ICSID Case No. ARB/05/8, Award (Sept. 11, 2007), available at http://ita.law.uvic.ca/documents /Pakerings.pdf), the court stated that there was no arbitrariness in the failure of Lithuania to disclose publicly available information because Lithuania had obtained a legal opinion that the plaintiff could receive such information from qualified firms. The Plaintiff also alleges that Lithuania had acted arbitrarily when its court rejected the force majeure argument as an excuse for the failure of investors to pay fees under an investment parking concession agreement with the city of Vilnius. Arbitral Tribunal believes that "erroneous judgment" by a court would not violate the treaty in the absence of a denial of justice, that is, a violation of the due process principle" (Parkerings-Compagniet AS vs Republic of Lith., ICSID Case No. ARB/05/8, Award (Sept. 11, 2007), available at http://ita.law.uvic.ca/documents/Pakerings.pdf.:313). 
Based on many cases he studied, Kenneth J. Vandevelde concludes that:

the reasonableness principle has been found only in the case of investment by animus toward the foreign investment or investor. Typically, the unlawful conduct is described as retaliatory or discriminatory, especially the wrong restrictions on the legitimate public policies, such as the foreign ownership of the investment (Kenneth J. Vandevelde:2010:.63).

\section{v. Element of Non-discrimination Principle}

Various BITs require the principle of non-discrimination by sharing the variation of the formula. Nevertheless the FET standard only prohibits unreasonable discriminations. For example, in the case of Saluka Invs. BV vs Czech Republic 2006,(Saluka Invs. BV vs Czech Republic, Partial Award (Perm. Ct. Arb. Mar. 17, 2006), accessed October26 ${ }^{\text {th }}, 2017$ at http://ita.law.uvic.ca/documents/Saluka-PartialawardFinal.pdf.) based on the BIT of Dutch and Czech, the court decided that the country violated the FET standard because the court did not find a reasonable basis in its discriminatory actions which provided financial assistance to three privately owned privatized banks but did not provide the same facilities to one other privatized bank owned by the plaintiffs of Dutch investors (Kenneth J. Vandevelde: 2010: 64). Likewise, in the case of Leewen Group, Inc. vs United State 2003, Methanex Corp. vs United States 2005, it was concluded that Discriminatory Measures violate FET standard only if they lack a reasonable justification. Nationality is not a reasonable discrimination. Discrimination may be justified only by legitimate and non-discriminatory purposes (Kenneth J. Vandevelde: 2010:66).

\section{vi. Element of Consistency}

The FET standard has been interpreted by the arbitrage Investor State Dispute Settlement (ISDS) that the state is required to provide a form of security to protect the investment in its territory. Specifically, this standard requires the host state to act in a consistent manner. However it does not mean that states should not change their policies at all times. The state has the discretion to change its policy. An offense occurs, only if the host's statements have promised to act in a certain way or have offered reasonable assurances to investors to implement. This means that the principle of consistency or security entitles investors to be protected by their expectations based on the promises made by the state (Kenneth J. Vandevelde: 2010:66). The promise or assurance must be made when the investor decides to invest.

In the case of Duke Energy vs Ecuador, based on the US BIT - Equador, arbitral tribunal declared no violation of FET standard as alleged investors, where 
the investment has been made 2 years before the arbitration agreement entered into force. The Tribunal states that the reasonableness of the investor's reliance should be evaluated based on the prevailing political, socio-economic, cultural, and historical conditions prevailing in the host state. In general the court limits the protection to expectations reasonable under the above conditions (Kenneth $\mathrm{J}$. Vandevelde:2010:67).

In the implementation of the principle of consistency it is important to distinguish between inconsistent behavior over time and inconsistent behavior that occurs simultaneously. The Tribunal accepts that sovereign states have the right to change their policies over time. It would be said that there is a violation of the principle of consistency if there are inconsistent behaviors from time to time in which the host state makes a commitment not to change its policy or to provide guarantees even if there is no formal contract. In contrast, inconsistent simultaneous behaviors are said to violate the standard even if no commitment or guarantees are provided by the host state. Nevertheless, the difference between behavioral in coordination over time and simultaneous behavior is sometimes slight. Successive actions by the host state can be said to violate the consistency standard that occur in relatively short periods of time, even if it is not simultaneously. Host states may change their laws or policies from time to time but changes in the roller coaster will violate the principle of consistency and security (Kenneth J. Vandevelde:2010:82).

In the case of PSEG vs Turkey, based on BIT the United States-Turkey, ICSID stated that Turkey violates FET standards by abusing its power. Many Turkish policies change (roller coaster changes in the law). Investors already ask to renegotiate and resolve the conflict that arises but the rights that investors have under this law are ignored (Kenneth J. Vandevelde: 2010:81-82).

The principle of consistency can be violated even though the host state does not change its laws over time but by inconsistent positions simultaneously. In case of MTD Equity vs Chile, under BIT of Malaysia-Chile, Chile encourages Malaysian companies to invest in a planned community building. Malaysian companies learn that community construction will violate local zoning laws and projects will not be realized. The tribunal found that the Chilean government's approval of a project that clearly violated the urban policy of the Government was a violation of the FET standard. The tribunal explained that Chile has its own obligation to act coherently and apply its policies consistently. "Thus Chile has made two inconsistencies simultaneously, namely: encouraging national level investment in which it is simultaneously forbade at the local level(Kenneth $\mathrm{J}$. Vandevelde:2010:82). 


\section{vii. Element of Transparency Principle}

Today there are no clear parameters about implementing transparency principles that violate FET standard. Principle of transparency is related to openness, clarity of administration and procedure-host state which means law and administration of host state must be clear, accessible and explicit (Dagbjort Hauksdottir: 2014: 31). Some court decisions state that FET standard violations occur when host state does not disclose the rule of law it applies, whether procedural or substantial, or when the state fails to provide the reason for its actions. (Dagbjort Hauksdottir: 2014: 83).

The principle of transparency is applied not only to host state law, but also to host state policy. Principle of transparency does not necessarily imply disclosure of internal deliberations, but host state is said to violate the principle of transparency when it refuses to open its policy when the policy has been adopted and does not allow access to information required by investors. In many cases plaintiffs are more successful using nondisclosure of policies than executive disclosure of laws. In case of MTD Equity vs Chile, (MTD Equity Sdn. Bhd. vs Republic of Chile, ICSID Case No. ARB / 01/7, Award, (May 25, 2004), 12 ICSID Rep. 6 (2007) it is considered previously that chili inconsistencies violate FET standard.

In addition, ICSID also indicated that the lack of Chile transparency also violates FET standard. Chile invited investors to work on the project but did not inform that the project violates its own national law (Kenneth J. Vandevelde: 2010: 84).

In contrast, in the case of Parkerings-Compagniet vs Lithuania, based on BIT Norway-Lithuania, ICSID dismisses investor claims that host state violates BIT for not disclosing its will to modify the law that gives effect to the detriment of investors. The Tribunal said investors should know that the legal situation in Lithuania is in the process of economic transition. They should hire a local consultant who advises on the amendment process undertaken by host state. The Tribunal states a different matter from the case of MTD Equity, in which case the state provides guarantees for investment (Kenneth J. Vandevelde:2010:85).

\section{viii. Element of Due process}

FET requires due process and prohibits denial of justice. In the case of Middle East Cement vs Egypt, ICSID Case No. ARB / 99/6, Award, (Apr.12, 2002), 7 ICSID Rep. 173 (2005) based on BIT Egypt -Greece, host state seized the plaintiff's vessel without prior notice that ICSID declared this to include taking over a plaintiff's assets not in accordance with the process of law and therefore violating the FET standard (Kenneth J. Vandevelde:2010:89). 
Meanwhile denial of justice will be violated if the plaintiff can prove: Azinian vs United Mexican States, ICSID Case No. ARB(AF)/97/2, Award (Nov. 1, 1999), 39 I.L.M. 537.

a. If the relevant courts refuse to entertain a suit,

b. If they subject it to undue delay,

c. If they administer justice in a seriously inadequate way,

d. If there is the clear and malicious application of the law.

In the case of Azinian vs Mexico, based on NAFTA, ICSID declared there was no misapplication of the law by Mexican courts, no denial of justice. What occurred was the misrepresentations concerning the contract under Mexican law.

\section{ix. Element of Good Faith Principle}

Some court decisions mention good faith in FET violation considering good faith is an element of the rule of law. Nevertheless, this principle is seldom used by the court. FET violations do not require bad faith (Kenneth J. Vandevelde: 2010:97).

In the case of Tecmed vs Mexico (Tecnicas Medioambientales TECMED SA vs United Mexican States, ICSID Case No. ARB (AF) / 00, 2, Award, (May 29,2003), 43 ILM 133) Mexico does not permit the plaintiff to renew his operating license solid waste disposal facility. It is due to the pressure from the community to remove the facility. ICSID declares prohibition of extension of permit is the effort to forcibly relocate the facility or it is not a transparent effort which implied a hidden purpose so that there has been violation of obligation of good faith, which requires reasonableness, consistency and transparency. Related to this good faith standard FET requires host state to provide treatment that does not affect the basic expectations of investors when he decided to invest in host state territory.

Foreign investors expect the host state to act consistently, free of ambiguity, and completely transparent in relation to investors, so that investors understand all the policy rules governing their investments, as well as the objectives of relevant policies and administrative practices or directives, and thus investors can plan of its investment and comply with the rules.

Foreign investors also expect the host state to consistently behave, not to void revoking pre-existing decisions or permits issued by the State or local government by taking over commitments. Investors also expect the State to use existing legal instruments governing the actions of investors or investments in accordance with the contents of such instruments, and not to revoke their investments in a manner incompatible with those instruments (Kenneth $\mathrm{J}$. Vandevelde:2010:98-99). 


\section{CLOSING}

Based on the above explanations, conclusions can be drawn as follows:

1. The FET standard has been in existence since Havana Charter which was followed by various FCN, BIT and various international and regional international investment agreements. Nevertheless there is still debate recently regarding the legal standing and scope of the FET standard. From the analysis conducted by the authors it is concluded that considering the FET standard is a very basic standard. It is found almost in all international agreements bilaterally, regionally and globally and quoted also in some arbitral tribunal decisions that the FET standard can be categorized as an international custom law binding all countries without seeing whether its national law regulates the FET standard or not. However, the elements contained in it are still multi interpretation.

2. Up to now FET standard elements are still debated. Nevertheless, there are some elements that are always mentioned by almost all international legal law writers and are quoted in some arbitral tribunal decisions. These elements are legitimate expectation; due process; denial of justice; rule of law; non discrimination; transparency; consistency; good faith; and reasonableness. The principle of reasonableness requires the host state to treat investors reasonably related to legitimate public policy objectives. Violation occurs when there is arbitrary conduct, especially related to motivation by animus to investors. The principle of non-discrimination prohibits discrimination except on the basis of legitimate public policy objectives and reasonableness. The principle of consistency permits changes to the policy as long as it does not conflict with the host state commitment or guarantees afforded to the investor. The principle of consistency prohibits simultaneous inconsistencies that make repeated changes in a short time (roller coaster change). Consistency also adds the principle of reasonableness. However, a reasonable change in policy will be prohibited if the host state has made a reasonable guarantee that policy changes will not occur. 


\section{BIBLIOGRAPHY}

\section{Books:}

Diehl, Alexandra, 2012, The core standard of international investor protection : fair and equitable treatment, Alphen aan den rijn, wolter Kluwer

Dolzer, Rudolf dan Christoph schreuer, 2012, Principle on international investment law, 2nd edition, Oxford university press

Dumberry, Patrick, 2016, The formation and identification of rule of customary of rule of international law in international investment law, Cambridge university press

Klager, Roland , 2011, Fair and equitable treatment in international investment law, Cambridge university press

Rubins, Noah D. \&\& N. Stephan Kinsella,2005, International Investment, Political Risk and Dispute Resolution : Apractitioner's Guide, Oceana Publications

Sornarajah, Muthucmaraswamy, 2004, The International Law on Foreign Investment, Cambridge Univ. Press

\section{Journals:}

Adede, A.O., "A Fresh Look at the Meaning of the Doctrine of Denial of Justice under International Law”, 14 THE CAN. Y.B. INT'L L. 72, 91 (1976).

Choudhury, Barnali, 2005, Evolution or Devolution: Defining Fair and Equitable Treatment in International Investment, Law, 6 J. World Inv. \& Trade

Dolzer, Rudolf , 2005, fair and Equitable treatment: A key standard in investment treaty, 39 Int'l Law. 87

Fry, James D. ; Odysseas G. Repousis, 2016, “Towards a new World For Investor -State Arbitration Through Transparancy,”, 48 N.Y.U. J. Int'l L. \& Pol. 795

Dagbjort Hauksdottir, the fair and Equitable treatment standard in international investment agreement, Thesis master of Law, Haskollin Reykjavik

Dumberry, Patrick, "The Practice of States as Evidence of Custom: An Analysis of Fair and Equitable Treatment Standard Clauses in States' Foreign Investment Laws", McGill Journal of Dispute Resolution, VOL 2 (2015-2016)

Haeri, Hussein, 2011, A Tale of Two Standards: 'Fair and Equitable Treatment' and the Minimum Standard in International Law, Arbitration International, Volume 27 Issue 1

J. Vandevelde, Kenneth , 2010," A Unified Theory of Fair and Equitable Treatment”, 43 N.Y.U. J. Int'l L. \& Pol. 
Kalicki, Jean \& Suzanne Medeiros, 20017, Fair, Equitable and Ambiguous: What is Fair and Equitable Treatment in International Investment Law 22 ICSID Rev. Foreign Inv. L.J. 24

Loewen Group, Inc. vs United States, ICSID Case No. ARB(AF)/ 98/3, Award (June 25, 2003), 42 I.L.M. 811.

Pinto-León, Ignacio, 2006, Fair and Equitable Treatment under International Law: Analzsing the Interpretation of the NAFTA article 1105.1 by NAFTA chapter 11 tribunal, 15-WTR Currents: Int'l Trade L.J. 3

Roman Picherack, J. , 2008, The Expanding Scope of the Fair and Equitable Treatment Standard: Have Recent Tribunals Gone Too Far? 9 J. World Inv. \& Trade 255

Schreuer, Christopher 2005, Fair and equitable treatment in arbitral practice, the journal of world investment and trade, Vol 6

Schreuer, 2005, Fair and Equitable Treatment in Arbitral Practice, 6 J. World Inv. \& Trade 357

Wisner, Robert, "The Modern View of the Fair and Equitable Treatmnet standard in the Review of Regulatory action by state", 20-AUT Int'l L. Practicum 129, Autum 2007

W Schill; Stephan, 2006; Fair and equitable treatment under investment treaties as an embodiment the rule of law, IILJ working paper 2006/6, Global administrative law series, NYU Law school

Vasciannie, Stephen, "The Fair and Equitable Treatment Standard in International Investment Law and Practice", 70 Brit. Y.B. Int'l L. 99

\section{Articles taken from websites:}

Indonesia for Global Justice, "Catatan Dari Sengketa Investasi \& Perdagangan Internasional Dari Churchill Mining Hingga Kasus Impor Di WTO Di Era Proteksionism, diakses treakhir 24 desember 2017 di http://igj.or.id/wp-content/uploads/2017/01/Akhir-dari-sengketa-perjanjian-Internasional.pdf

Matthew Coleman, Helen Aldridge, Thomas Innes, 2015, "Investor-State Arbitration and "Fair and Equitable" Treatment, diakes 30 januari 2018 di https:// www.steptoe.com/publications-10464.html

Olatokunbo Lad-Ojomo, What is the distinction between The Fair and Equitable Treatment standard and Minimum Standard of Treatment under customary international law, paper, University ofDundee, diakses 2 pebruari di http://citeseerx.ist.psu.edu/viewdoc/download?doi=10.1.1.473.6169\&rep=rep1\&type $=$ pdf 


\section{Theses,:}

Dagbjort Hauksdottir, 2014, the fair and Equitable treatment standard in international investment agreement, thesis master of Law, Haskollin Reykjavik

\section{Documents:}

Agreement between the Government of the Republic of Indonesia and The Government of Australia Concerning The promotion and protection of Investment

Agreement between the government of republic of Indonesia and the government of The United Kingdom of great Britain and northern Ireland for the promotion and protection of investment

Award on Respondent's Preliminary Objections to Jurisdiction and Admissibilityof the Claims, He Sham Talaat M.Al Al Warraq vs Republic of Indonesia, $21106 / 2012$

Azinian vs United Mexican States, ICSID Case No. ARB(AF)/97/2, Award dated 1 Nov. 1999, 39 I.L.M. 537 (2000).

Genin vs Estonia, ICSID Case No. ARB/99/2, Award (June 25, 2001), 17 ICSID Rev. - ForeignInv. L.J. 395 (200

ICSID Case No. ARB(AF)/00/3, Award, P 98 (Apr. 30, 2004), 43 I.L.M. 967.

Noble Ventures, Inc. vs Romania, ICSID Case No. ARB/01/11, Award (Oct 12, 2005), available at http://ita.law.uvic.ca/ documents/Noble.pdf.

Organization for Economic Co-operation and Development (OECD), Draft Convention on the Protection of Foreign Property, Oct. 12, 1967, 7 I.L.M. 117, 119

Parkerings-Compagniet AS vs Republic of Lith., ICSID Case No. ARB/05/8, Award (Sept. 11, 2007), available at http://ita.law.uvic.ca/documents/Pakerings. pdf.

Persetujuan antara Pemerintah republic Indonesia dan Pemerintah Republik India mengenai peningkatan dan Perlindungan atas penanaman Modal

Rafat Ali Rizv vs Republic of Indonesia, (ICSID Case No. ARB/11/13)

Saluka Invs. BV vs Czech Republic, Partial Award (Perm. Ct. Arb. Mar. 17, 2006), available at http://ita.law.uvic.ca/documents/Saluka-PartialawardFinal.pdf.

Treaty of Friendship, Commerce and Navigation, Oct. 29, 1954, U.S.-F.R.G., 273 U.N.T.S. 4.

Waste Mgmt., Inc. vs United Mexican States, ICSID Case No. ARB(AF)/00/3, Award (Apr. 30, 2004), 43 I.L.M. 967 